REVISTA de

PEDAGOGIE

\title{
PAUL A. KIRSCHNER, CARL HENDRICK. HOW LEARNING HAPPENS. SEMINAL WORKS IN EDUCATIONAL PSYCHOLOGY AND WHAT THEY MEAN IN PRACTICE. London and New York, Routledge, 2020, 309 pages, ISBN 978-0-367-18456-8
}

PAUL A. KIRSCHNER, CARL HENDRICK. CUM ARE LOC ÎNVĂȚAREA. LUCRĂRI PROMIȚĂTOARE ÎN PSIHOLOGIA EDUCAȚIEI ȘI IMPORTANȚA ACESTORA PENTRU PRACTICĂ. Londra și New York, Routledge, 2020, 309 pagini, ISBN 978-0367-18456-8

\section{Carol CĂPIȚĂ}

Journal of Pedagogy, 2020 (2), 239 - 242

https://doi.org/10.26755/RevPed/2020.2/239

The online version of this article can be found at: $\underline{\text { http://revped.ise.ro/en/2020/ }}$

\section{(c)}

This work is licensed under the Creative Commons Attribution-NonCommercial-ShareAlike 4.0 International License To view a copy of this license, visit http://creativecommons.org/licenses/by-nc-sa/4.0/ or send a letter to Creative Commons, PO Box 1866, Mountain View, CA 94042, USA.

Published by:

Centrul Național de Politici și Evaluare în Educație

UNITATEA DE CERCETARE ÎN EDUCAȚIE

http://www.ise.ro/

https://rocnee.eu/

Further information about Revista de Pedagogie - Journal of Pedagogy can be found at:

Editorial Policy: http://revped.ise.ro/editorial-policy/

Author Guidelines: http://revped.ise.ro/en/author-guidelines/ 


\title{
PAUL A. KIRSCHNER ŞI CARL HENDRICK. HOW LEARNING HAPPENS: SEMINAL WORKS IN EDUCATION
}

Abingdon, Oxon \& New York, Routledge, 2020, 309 pagini, ISBN 978-0-367-18456-8

\section{Carol Căpi ă}

\author{
Universitatea din Bucureşti, \\ Facultatea de Istorie, \\ Bucureşti, România \\ carol.capita@istorie.unibuc.ro
}

Volumul semnat de cei doi autori reprezintă un tip special de reflec ie asupra educa iei, în orice caz un text cu o scriitură în egală măsură tradi ională şi inovatoare, iar un echilibru între tradi ional şi novator nu este niciodată uşor de atins. Chiar şi titlul ales, Cum are loc învă area: lucrări fundamentale din psihologia educa iei şi ce înseamnă ele pentru practică, indică miza lucrării, anume aceea de a combina reflec ia teoretică cu practică şcolară. Este un text care atrage aten ia asupra rela iei dintre teorie şi practică, dintre reflec ia născută din cercetarea fenomenului educa ional şi solu iile practice utilizate în clasă. De altfel, P. A. Kirschner este (co)autorul mai multor lucrări, unele dedicate TIC în educa ie, altele educa iei în general care sunt axate pe problema complexită ii procesului de predare-învă are dar şi pe analiza miturilor legate de procesul educa ional ${ }^{1}$ (2010, 2015, 2018). Deşi textul porneşte, în toate cele 29 de capitole ale sale, de la tot atâtea articole, el reprezintă mai mult decât o culegere sau parafrazare a unor texte academice.

Textul, înso it de numeroase scheme care ilustrează punctele teoretice formulate în text şi de casete tematice (care cuprind mici texte referitoare la personalită i ale domeniului, teorii formulate cu privire la învă are şi predare, sau experimente de psihologie a învă ării), este structurat în şase păr i care încearcă să acopere întregul câmp conceptual asumat prin titlu. Pornind de

* Prof. univ. dr., Universitatea din Bucureşti, Facultatea de Istorie, Bucureşti, România. 
la explicarea fundamentelor neurologice ale învă ării şi ale memoriei, textul abordează (în succesiune) prerechizitele necesare învă ării, activită ile care o sus in, rolurile profesorului, contextul învă ării şi o parte finală dedicată mai degrabă dimensiunii morale care subîntinde problematica învă ării.

Prima parte, dedicată cogni iei, ridică o serie de probleme legate atât de substratul neurologic, cât şi de fundamentarea, în psihologia emo iilor, a actului învă ării. Faptul că învă area este un fenomen atât biologic, cât şi cultural pare să fie clar în momentul în care este introdusă şi dimensiunea tipului de comunicare. Fără a o spune ca atare, autorii par să fie de acord cu ideea că elevii înva ă diferit şi că în practica şcolară este important să combinăm diferitele medii de comunicare a informa iei (dar vezi şi cap. 29, în care aceştia resping teoria stilurilor de învă are). A doua parte continuă abordarea cognitivistă, de data aceasta pornind de la teoriile formulate de Bandura şi, cam în acelaşi timp, de Ausubel. Faptul că cunoaşterile anterioare determină atât eficacitatea învă ării, cât şi reten ia informa iei este fundamental. Până la urmă, elevii nu sunt o pagină albă pe care cadrul didactic o poate amprenta cum consideră el/ea de cuviin ă. Dimpotrivă, elevii aduc cu ei o încărcătură de cunoaştere mai mare sau mai mică, mai apropiată sau mai depărtată de dimensiunea scolastică, dar în orice caz, bine ancorată (mai ales emo ional) în experien ele lor cotidiene. Ignorarea acestei dimensiuni poate reduce mult din eficien a învă ării. A treia parte, dedicată unor tehnici de predare şi învă are, continuă pe aceiaşi linie, anume analiza critică a unor termeni mai degrabă invoca i decât aplica i în practică. Ceea ce par să afirme autorii este că tehnicile de predare-învă are trebuie să fie în egală măsură eficiente şi plăcute. Dar capitolele acestei păr i nu sunt o simplă înşiruire de metode; mai degrabă sunt capitole (mai ales capitolul al 15-lea) care dau consisten ă teoretică unor metode deja folosite în şcoală. Regăsim aici unul din pilonii întregului volum, anume importan a teoriei pentru practică, căci într-adevăr consisten a teoretică este cea care duce la practica informată. Următoarele capitole, adunate sub titlul modest Profesorul, continuă analiza tehnicilor de predareînvă are. Dincolo de cadrul teoretic, ceea ce este semnificativ şi în continuarea abordărilor propuse de Marzano şi echipa din jurul său este efortul de a identifica tehnicile eficiente fără a le clasifica în moderne şi/sau clasice (cap. 21, în special). Această problemă a discriminării între clasic şi modern este una fundamentală, căci dincolo de modernitate, eficien a este criteriul fundamental; au fin de compte, trebuie să vedem în ce măsură o 
tehnică modernă de predare-învă are aduce plus-valoare (dacă presupune mai mult timp consumat în raport cu intele educa ionale, de pildă, este o metodă inadecvată - ceea ce nu înseamnă că ar fi ineficientă). Ceea ce realizează această a cincea parte este, de fapt, un sumar integrativ al problemelor ridicate în paginile anterioare ale căr ii şi o prezentare (nedeclarată) a complexită ii factorilor implica i în învă area de succes. Ultima parte este mai degrabă un caveat cu privire la riscurile legate de proasta în elegere a fenomenului învă ării, fie din acceptarea necritică a unor teorii şi aplicarea lor mecanică la clasă, fie din respingerea dimensiunii informative pe care o dă o posibilă fundamentare teoretică. De altfel, ultimul capitol, intitulat semnificativ Cele zece păcate de moarte în educa ie, este şi o analiză pertinentă cu privire la o serie de mituri educa ionale care invadează atât practica şcolară, cât şi discursul public cu privire la educa ie.

Dar textul celor doi autori este mai mult decât o analiză pertinentă şi uşor de citit a teoriei şi practicilor învă ării. Felul în care este organizat textul reprezintă o construc ie meta-analitică menită să conducă cititorul spre analiza propriilor sale fundamentări teoretice şi experien e educa ionale practice. Textul fiecărui capitol porneşte de la un articol considerat fundamental (în formularea autorilor, imposibil de tradus în limba română altminteri decât generator de şcoală) şi este structurat pe câteva puncte: de ce merită să fie citit articolul, rezumatul acestuia, prezentarea sintetică a acestuia, implica ii pentru practica şcolară, cum pot fi utilizate concluziile în practica şcolară, idei cheie (,takeaways”), resurse suplimentare (în cheia preocupărilor autorilor, acestea sunt disponibile online cu ajutorul unui cod QI). Pe cale de consecin ă, textul poate fi extrem de util atât practicienilor, cât şi celor preocupa i de o abordare teoretică. Şi poate că aici se află un alt pilon important al perspectivei oferită de cei doi autori. Discu ia (foarte prezentă în şcoala şi societatea românească) despre diseminarea elementelor de bună practică ridică problema rela iei dintre teorie şi practică, centrală pentru textul de fa ă. De fapt, ce leagă două experien e (pozitive) din contexte şcolare adesea foarte diferite? Mai bine, cum pot fi acestea rela ionate? O analiză sumară va indica faptul că elementul care poate asigura transferul unei experien e pozitive într-un alt context educa ional este teoria, în eleasă ca mecanism fundamentat de analiză a celor două situa ii concrete şi de reducere a informa iei la esen ialul transferabil. Credem că textul lui Kirschner şi Hendrick tocmai acest lucru îl demonstrează, anume func ia adaptativă a teoriei şi rolul acesteia în 
structurarea unei învă ări de calitate. În plus, faptul că fiecare capitol porneşte de la un studiu considerat fundamental este foarte important, căci permite cititorului să vadă cum se construieşte cunoaşterea şi, la fel de important, cum poate fi aplicată aceasta la practica şcolară. Din acest punct de vedere, volumul de fa ă reprezintă o contribu ie fundamentală (şi o lectură plăcută şi stimulativă) la literatura de specialitate.

\section{NOTE}

1 Wolpers, M., Kirschner, P.A., Scheffel, M., Lindstaedt, S., \& Dimitrova, V. (Eds.). (2010, September 28 - October 1). Sustaining TEL: From Innovation to Learning and Practice. 5th European Conference on Technology Enhanced Learning, EC-TEL 2010 Barcelona, Spain, Proceedings Springer-Verlag.

de Bruyckere, P., Kirschner, P.A., \& Hulshof, C.D. (2015). Urban Myths about Learning and Education. Elsevier.

van Merrienboer, J.J.G., \& Kirschner, P.A. (2018). Ten steps to complex learning: a systematic approach to four-component instructional design (3rd ed.). Routledge.

The online version of this article can be found at: http://revped.ise.ro/category/2020-en/

\section{(CC) EY-NC-BA}

This work is licensed under the Creative Commons Attribution-NonCommercial-ShareAlike 4.0 International License.

To view a copy of this license, visit http://creativecommons.org/licenses/by-nc-sa/4.0/ or send a letter to Creative Commons, PO Box 1866, Mountain View, CA 94042, USA.
Versiunea online a acestui articol poate fi găsită la: http://revped.ise.ro/category/2020-ro/

\section{(cc) DY-NC-EA}

Această lucrare este licen iată sub Creative Commons Attribution-NonCommercial-ShareAlike 4.0 International License.

Pentru a vedea o copie a acestei licen e, vizita $i$ http://creativecommons.org/licenses/by-nc-sa/4.0/ sau trimite i o scrisoare către Creative Commons, PO Box 1866, Mountain View, CA 94042, SUA. 